\title{
Subacute bilateral vision loss resulting from dengue maculopathy
}

\author{
Tasanee Braithwaite, ${ }^{1}$ Laura Nabarro, ${ }^{2}$ Adnan Tufail ${ }^{3}$
}

${ }^{1}$ Department of Ophthalmology, The Whittington Hospital, London, UK

${ }^{2}$ Department of Microbiology, The Whittington Hospital,

London, UK

${ }^{3}$ Moorfields Eye Hospital NHS Foundation Trust, London, UK

\section{Correspondence to} Dr Tasanee Braithwaite, tasaneebraithwaite@gmail.com

\section{DESCRIPTION}

A 23-year-old woman with a 5-day history of fever and headache presented to the accident and emergency department with blurred central vision and a

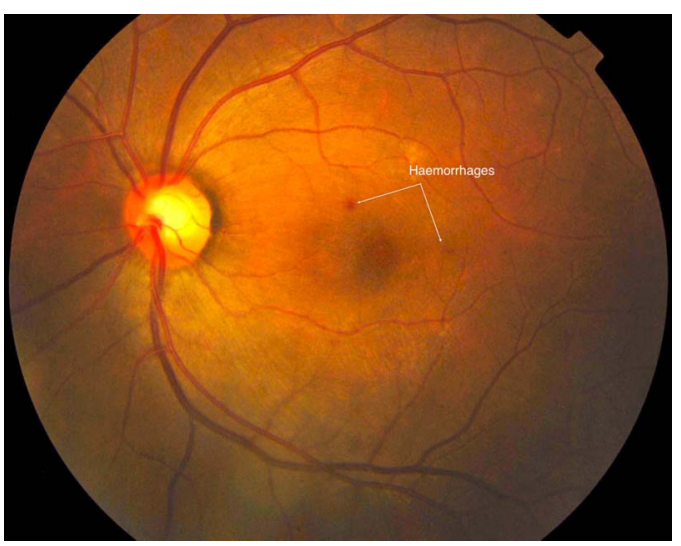

Figure 1 Retinal fundus photograph of left eye showing occasional small flame haemorrhages. macular rash. She had returned from Thailand 1 week earlier. Laboratory investigations revealed moderate thrombocytopenia and elevated hepatic aminotransferases. A diagnosis of dengue was made by serum PCR. Her visual acuity was $6 / 9$ bilaterally, but decreased to $6 / 36$ on the right and 'hand movements' on the left over $48 \mathrm{~h}$, and she described dense central scotomas. Fundoscopy revealed occasional flame haemorrhages (figure 1), and fundus fluorescein angiography was unremarkable. Optical coherence tomography (OCT) initially showed bilateral diffuse intraretinal and subfoveal fluid (figure 2). Bilateral disruption of the foveal outer retina developed 2 days later (figure 3). Oral prednisolone $60 \mathrm{mg}$ was started, tapering over 6 weeks, and her visual acuity improved to $6 / 18$ bilaterally 3 weeks later, with subjective reduction in density of scotoma.

Each year there are over 50 million cases of dengue, a mosquito-borne flaviviral infection endemic in urban areas of the tropics. ${ }^{1}$ Dengue maculopathy has only emerged in recent decades, and was reported in $10 \%$ of hospitalised patients

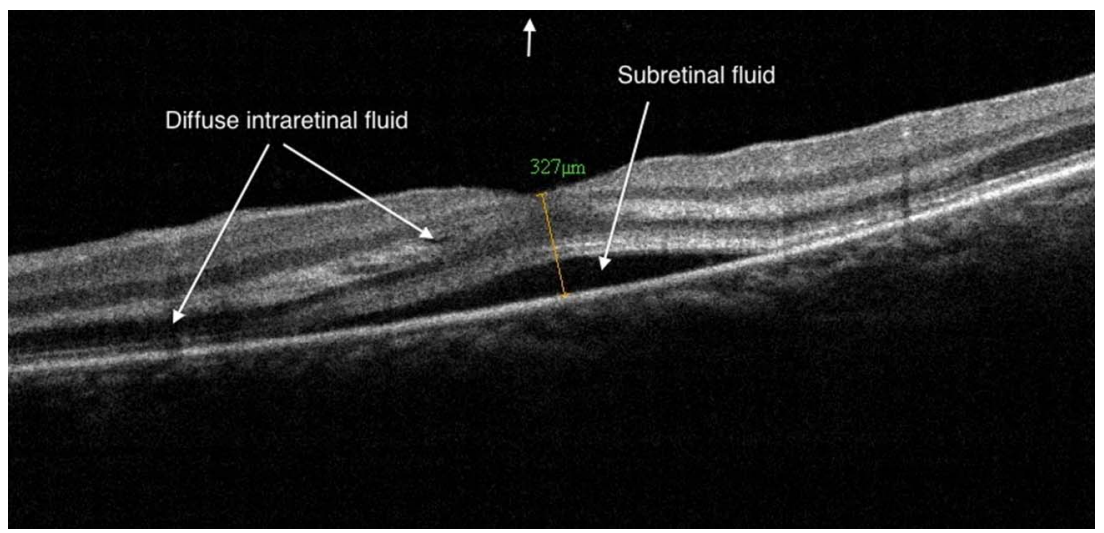

Figure 2 Optical coherence tomography image of left eye 1 day after the onset of visual symptoms, when visual acuity was $6 / 9$, demonstrating intraretinal and subretinal fluid.

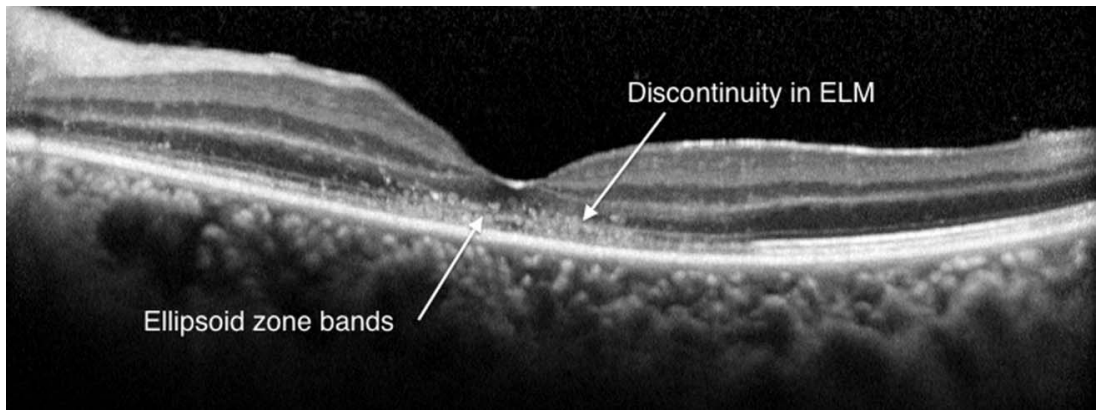

To cite: Braithwaite $T$ Nabarro L, Tufail A. BMJ Case Rep Published online: [please include Day Month Yearl doi:10.1136/bcr-2013200542

Figure 3 Optical coherence tomography image of left eye 5 days after the onset of visual symptoms, when visual acuity was 'hand movements', demonstrating localised disruption of the outer neurosensory retina at the fovea. 
during the 2005 Singapore epidemic. $^{2}$ It is thought to result from increased vascular permeability and serotype-dependent immune-mediated disruption of outer retinal layers. ${ }^{2}$ Three OCT patterns are recognised, which aid diagnosis and monitoring: diffuse retinal thickening, cystoid macular oedema and foveolitis. $^{3}$ Visual acuity recovers over several months in the majority, but scotoma frequently persist. ${ }^{3}$ There is no established treatment, but steroids may be beneficial.

\section{Learning points}

- Dengue fever is the commonest mosquito-borne viral disease globally, and while ocular complications are rare, these have been reported with increasing frequency in recent decades.

- Clinical examination findings can be subtle (scanty haemorrhages at the macula) but vision loss may be profound, and typically develops a week after the onset of fever.

- Spectral-domain optical coherence tomography is especially valuable for making the diagnosis and monitoring progress, and three patterns are typically seen: diffuse retinal thickening, cystoid macular oedema and photoreceptor layer abnormalities. The latter has the worst visual prognosis.
Acknowledgements We thank Professor Stephen Teoh and colleagues at the Eye Institute, Tan Tock Seng Hospital, Singapore, for their guidance in the management of this patient.

Contributors All authors were directly involved in the management of the patient and in the preparation and review of this manuscript.

Competing interests None.

Patient consent Obtained.

Provenance and peer review Not commissioned; externally peer reviewed.

\section{REFERENCES}

1 Simmons CP, Farrar JJ, Nguyen VV, et al. Dengue. N Engl J Med 2012;366:1423-32.

2 Su DH, Bascal K, Chee $\mathrm{S}$, et al. Prevalence of dengue maculopathy in patients hospitalized for dengue fever. Ophthalmology 2007;114:1743-7.

3 Teoh SC, Chee CK, Laude A, et al. Optical coherence tomography patterns as predictors of visual outcome in dengue-related maculopathy. Retina 2010;30:390-8.

Copyright 2013 BMJ Publishing Group. All rights reserved. For permission to reuse any of this content visit http://group.bmj.com/group/rights-licensing/permissions.

BMJ Case Report Fellows may re-use this article for personal use and teaching without any further permission.

Become a Fellow of BMJ Case Reports today and you can:

- Submit as many cases as you like

- Enjoy fast sympathetic peer review and rapid publication of accepted articles

- Access all the published articles

- Re-use any of the published material for personal use and teaching without further permission

For information on Institutional Fellowships contact consortiasales@bmjgroup.com

Visit casereports.bmj.com for more articles like this and to become a Fellow 